\title{
Feeding Anglo-Saxon England: the bioarchaeology of an agricultural revolution
}

\author{
Helena Hamerow ${ }^{1, *}$, Amy Bogaard ${ }^{1}$, Mike Charles ${ }^{1}$, \\ Christopher Ramsey ${ }^{1}$, Richard Thomas ${ }^{2}$, Emily Forster ${ }^{1}$, \\ Matilda Holmes ${ }^{2}$, Mark McKerracher ${ }^{1}$, Samantha Neil ${ }^{2}$ \\ \& Elizabeth Stroud ${ }^{1}$
}

The early Middle Ages saw a major expansion of cereal cultivation across large parts of Europe thanks to the spread of open-field farming. A major project to trace this expansion in England by deploying a range of scientific methods is generating direct evidence for this so-called 'Medieval Agricultural Revolution'.

Keywords: Anglo-Saxon, Middle Ages, cereal, agriculture

The period between $c$. AD 800-1200 saw dramatic changes in farming practices across large parts of Europe, resulting in an increase in cereal production so great that it has been described as an agricultural revolution (White 1940; Duby 1954). This 'cerealisation' supported rapid population growth and fuelled the expansion of towns and markets. Three key innovations made this increase in yields possible: two- and three-field crop rotation; widespread adoption of the mouldboard plough, enabling farmers to cultivate heavier, more fertile soils; and extensification of cultivation, whereby fertility was maintained not by intensive manuring or long fallow periods, but by short fallow cycles during which sheep-whose droppings fertilised the fields - grazed on stubble and weeds. This allowed the area of land under cultivation to expand substantially without a comparable expansion of input in terms of labour and manure.

To operate this more productive but costly system of farming, peasants shared expensive resources such as teams of oxen and mouldboard ploughs, and cultivated extensive, unenclosed fields communally. The need to coordinate cultivation activities is thought to lie behind the formation of the nucleated villages that still characterise many parts of the countryside today. In this way, innovations in farming transformed not only large parts of England's landscape, but also its social geography. Until now, however, researchers have been forced to rely on a limited range of indirect evidence, written and archaeological, to infer when, where and how this unprecedented form of agriculture emerged. This has led to over a century of debate about the significance of its impact on Anglo-Saxon England.

1 School of Archaeology, University of Oxford, 34-36 Beaumont Street, Oxford OX1 2PG, UK

2 Department of Archaeology and Ancient History, University of Leicester, University Road, Leicester LE1 7RH, UK

* Author for correspondence (Email: helena.hamerow@arch.ox.ac.uk)

(C) Antiquity Publications Ltd, 2019

ANTIQUITY 93 368, e12 (2019): 1-4

https://doi.org/10.15184/aqy.2019.27 


\section{The 'FeedSax' project}

A four-year project to trace the expansion of cereal production in England is deploying a range of scientific methods together with settlement archaeology to generate new data and advance this long-standing debate. The project, which began in 2017 and is funded by the European Research Council (AdG741751; PI Hamerow), is based at the Universities of Oxford and Leicester.

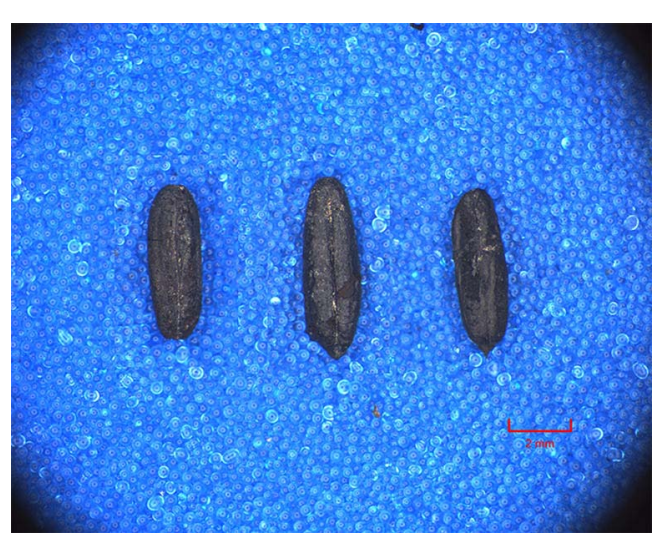

Figure 1. Charred cereal grains from Stafford.

FeedSax aims to trace the spread of the 'mouldboard plough package'-i.e. crop rotation, use of the mouldboard plough and extensification-by generating direct evidence of medieval land use and cultivation regimes from excavated plant remains and animal bones. Analysis of stable isotopes in preserved cereal grains and the bone collagen of sheep will enable us to assess the degree to which productivity was boosted by manuring (Figure 1); weed flora will also reveal the extent to which fields were manured and tilled, as well as provide evidence of sowing times and crop rotation (Figure 2). The lower limb bones of cattle will be examined for pathologies caused by pulling a heavy plough. Pollen data will reveal the changing impact of cereal farming on the medieval landscape and will be used to produce the first national model of early medieval land use. Patterns emerging from these bioarchaeological data will then be compared with the evidence from excavated farms- - buildings, enclosures, droveways and the like- to explore the inter-relationship between arable production, stock management and settlement forms. Finally, a suite of over 400 radiocarbon dates on charred cereals, bones and pollen cores will make it possible to locate accurately the spread of open fields in time and space.

\section{Preliminary results}

In addition to producing a national database of charred plant remains, pollen and animal bones dating to this period, the project is undertaking detailed scientific analysis of case studies from different regions of England, and comparative analysis of material from the Rhineland (Figure 3). The analysis of the weed flora and crop stable isotopes from one of the case-study sites - the Anglo-Saxon burh of Stafford in the West Midlands — has already produced evidence to suggest a shift to larger-scale, lower-input (i.e. more extensive) cultivation in the tenth to eleventh centuries $\mathrm{AD}$. Furthermore, the crop stable isotope evidence suggests wetter growing conditions during the same period. This is likely to indicate a shift from lighter, dryer soils to heavier, more fertile soils, while pollen evidence from the immediate vicinity suggests that increased precipitation played a role, an intriguing finding given that the period in question comes at the start of what is often referred to as the 'Medieval Warm Period'.

(C) Antiquity Publications Ltd, 2019 


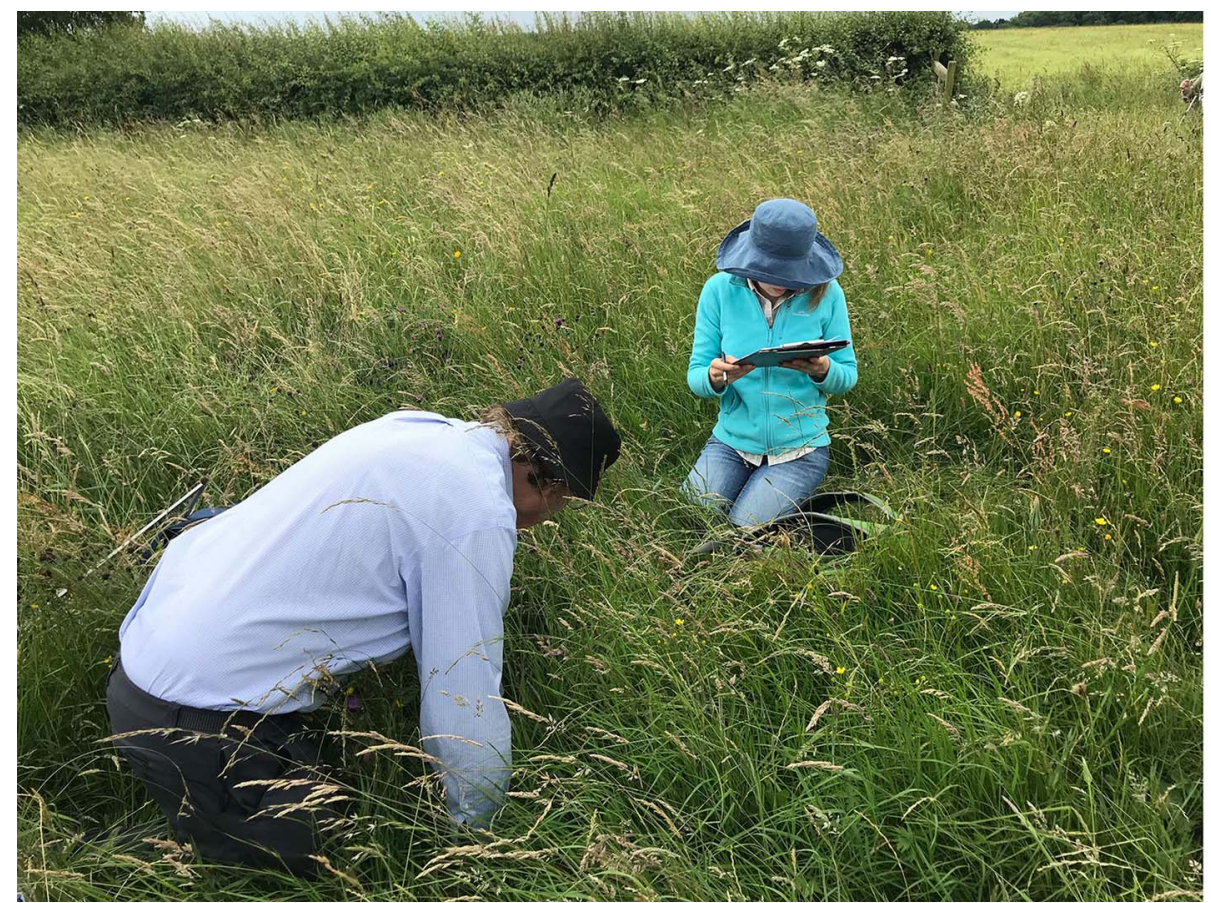

Figure 2. Archaeobotanical survey being conducted at Laxton (Nottinghamshire), England's last open-field village. Laxton offers the opportunity to study the species composition and ecology of vegetation communities adapted to the existing version of the open-field system with three-field rotation, as well as ancient hay meadows that fill the uncultivated interstices of the arable landscape.

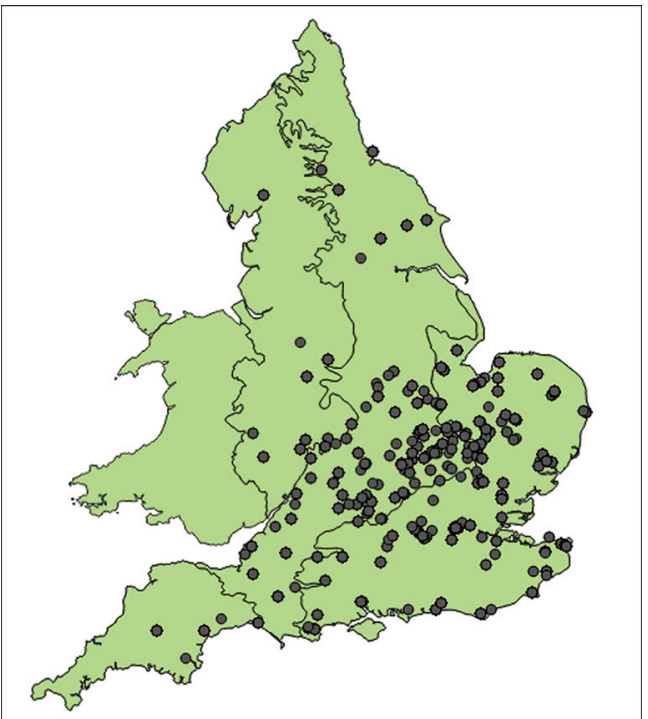

Figure 3. Distribution of the 274 sites that have produced medieval charred plant remains, in relation to Roberts \& Wrathmell's (2002) settlement provinces.
A large assemblage of charred plant remains from the Rhineland, provided by colleagues at the University of Cologne, presents us with the opportunity to trace the long-term trajectory of cereal farming from the Neolithic to the thirteenth century in a region of Europe that underwent comparable 'cerealisation' in the early medieval period. The weed flora reflect a consistent trend towards larger-scale, lower-input cultivation regimes from the Neolithic onwards, peaking during the Roman period. The data suggest broad continuity through the fifth and sixth centuries, with no significant reversal of this trend until the seventh and eighth centuries, when there appears to have been some shift towards smaller-scale, higherinput (i.e. more intensive) farming methods. Not until the tenth century and beyond do

(C) Antiquity Publications Ltd, 2019 
we see evidence of a clear shift to more extensive—potentially open-field—farming. Even at this relatively late date, however, the picture is mixed, with some persistence of more intensive regimes.

\section{References}

Duby, G. 1954. La révolution agricole médiévale. Revue de Géographie de Lyon 29: 361-66. https://doi.org/10.3406/geoca.1954.2010

White, L. 1940. Technology and invention in the Middle Ages. Speculum 15: 141-59. https://doi.org/10.2307/2849046

Roberts, B. \& S. Wrathmell. 2002. Region and place: a study of English rural settlement. London: English Heritage.

Received: 23 October 2018; Accepted: 26 November 2018; Revised: 29 January 2019

(C) Antiquity Publications Ltd, 2019 